\title{
Editorial
}

Lourdes M. Bandeira, Ana Cristina M. Collares \& Tânia Mara C. Almeida*

A s editoras do presente número de Sociedade e Estado têm a satisfação de apresentar um dossiê que certamente se tornará referência no país e na América Latina no campo dos estudos decoloniais intersecionados aos estudos raciais, "Decolonialidade e perspectiva negra". Organizado pelos professores Joaze Bernardino-Costa (Departamento de Sociologia/UnB) e Ramón Grosfoguel (Universidade da Califórnia - Berkeley/Estados Unidos), o dossiê é composto por cinco artigos de renomados/as estudiosos/as internacionais: Ramón Grosfoguel (Universidade da Califórnia - Berkeley/Estados Unidos), Enrique Dussel (Universidad Autónoma Metropolitana - Iztapalapa e Universidad Nacional Autónoma de México/México), Nelson Maldonado-Torres (Rutgers University/Estados Unidos), Patricia Hill Collins (Universidade de Maryland e Universidade de Cincinnati/Estados Unidos) e Linda Alcoff (Hunter College e City University of New York/Estados Unidos). Alguns desses artigos são traduções de importantes textos originalmente publicados fora do país e, portanto, não há traduções presentes neste número em separado, como foram apresentadas ultimamente. Os demais artigos são publicações inéditas para a nossa revista.

A partir dos próximos fascículos, dossiês serão organizados de modo intercalado com edições formadas apenas por artigos recebidos via fluxo contínuo, de acordo com a linha adotada pelo Comitê Editorial a partir de 2016. Afinal, a revista tem sido procurada com grande frequência por autores/as assinantes de excelentes textos, os quais necessitam ser divulgados com celeridade e menor tempo entre a data de submissão e sua disponibilização ao público leitor.

A seção de artigos de fluxo contínuo está formada por cinco manuscritos de diversos temas, abordagens teóricas e metodológicas. Estes são:

"Novos padrões de investigação policial no Brasil", de autoria de Arthur Trindade Maranhão Costa (UnB) e Almir de Oliveira Júnior (Ipea), descreve e analisa casos de investigação policial denunciados pelo Ministério Público em nove estados brasileiros e arquivados no ano de 2011. Este conjunto apresenta-se como um novo padrão investigatório e traz efeitos significativos às sentenças, estabelecendo-se a partir de mudanças de atitudes dos profissionais do Sistema de Justiça Criminal.

* Professoras do Departamento de Sociologia da Universidade de Brasília. 
"As correspondências entre José Enrique Rodó e Miguel de Unamuno: o reencontro intelectual da Pátria Mãe com a Pátria Filha", por Elisângela da Silva Santos (Universidade Complutense/Madrid), analisa correspondências trocadas entre os autores José Enrique Rodó (1871-1917) e Miguel de Unamuno (1864-1936), onde se observa um projeto intelectual de intercâmbio de ideias e relações entre a Espanha e a América Latina. Os seguintes temas são destacados como elementos de aliança entre os países no processo de colonização: os debates em torno de seus livros; a construção de um espírito coletivo com vistas a uma aproximação entre a Antiga Pátria Mãe e a Antiga Pátria Filha; suas produções ensaísticas; as condições políticas e históricas que vivenciavam Espanha e Uruguai; o positivismo e o idealismo; por fim, a religião e a ciência.

O terceiro artigo, de autoria conjunta de Enrique Pastor Seller (Universidad de Murcia) e Margarita Sánchez Millán (Servicios Sociales del Muicípio de Beniel/Murcia), "Estudio del impacto y efectos de la crisis económica em las políticas de protección social del âmbito local en España", realiza uma análise de caso da região de Murcia por meio de uma pesquisa longitudinal de necessidades e serviços entre 1996 e 2011. Os resultados apontam para a mudança do perfil dos usuários estar diretamente relacionado com as dinâmicas da crise socioeconômica e o desenvolvimento das políticas de bem-estar social.

José Veríssimo Romão Netto (USP) escreveu o artigo “Estrutura administrativa do governo brasileiro, cultura política e busca pela sociedade ideal", que trata da transformação da organização e estrutura do governo central brasileiro entre a monarquia e o atual período democrático (1985). Contudo, uma interessante aproximação teórica é assinalada entre autores que têm refletido e atuado sobre essa estrutura. "Eles propugnaram que por intermédio da reforma da estrutura político-administrativa do Estado seria possível mudar a cultura política do povo brasileiro".

Por fim, "Processos de racionalização e novos desenhos identitários: a reestruturação da indústria da reparação automotiva e do ofício do mecânico", assinado por Laura Senna Ferreira (UFSM), busca compreender a elaboração de novos desenhos identitários em uma categoria laboral com intensificação dos processos de racionalização do trabalho e da indústria a partir dos anos 1990: o ofício de mecânico na reparação automotiva. Em um estudo de caso em Porto Alegre (RS), observa e analisa-se a maneira pela qual esses sujeitos têm resistido e/ou negociado com tais exigências, redimensionando suas identidades.

Quanto às resenhas deste número, apresentamos uma elaborada por Marcelo Augusto de Almeida Teixeira (doutorando PPGSOL/UnB), a respeito da obra Ruth Levitas, Utopia as method: the imaginary reconstitution of society (New York: Palgra- 
ve MacMillan, 2013). A outra, intitulada "E se Deus fosse um ativista dos Direitos Humanos?", por Éverton Garcia da Costa (doutorando PPGS/UFRGS), se refere ao livro de nome similar de Boaventura de Sousa Santos, Se Deus fosse um ativista dos direitos humanos (São Paulo: Cortez, 2013).

Como de praxe, resumos de dissertações e teses encerram o fascículo do nosso periódico. Contudo, este material não se encontra mais disponível na plataforma de livre acesso SciELO, apenas em outras bases de nossa revista e na nossa versão impressa.

Com pesar, expressamos neste editorial a indignação e a perplexidade pelo assassinato da estudante de biologia da UnB, Louise Maria da Silva Ribeiro, pelo seu colega de curso nas dependências da universidade por não aceitar o fim do relacionamento amoroso. Em sua homenagem e às mulheres que se empenham cotidianamente a usufruírem as possibilidades de estudo, trabalho e autonomia individual, em uma vida sem violência, divulgamos aqui o poema da Lílian Gisele Fraga (graduanda em ciências sociais/UnB), escrito justamente no mês internacional da mulher, dias após o referido feminicídio e outro que vitimou a também jovem Jane Carla, no Distrito Federal, pelo mesmo motivo.

\section{Requiem in aeternum}

Em memória de Louise Ribeiro e Jane Carla

Pai, por que me abandonastes?

Clamou o filho de Deus.

Deus, por que nos repudiastes?

Clamam as filhas dos homens.

Nem a mãe do Cristo foi poupada

Nem as mães das mulheres queimadas

Nas fogueiras da Santa Inquisição.

Negar Deus não cumpre meu intento

Porém pergunto-vos embora em vão

Se vos comprazei de nosso tormento.

Pois que na Terra não temos Justiça

Para nossos corpos aos abutres lançados

Antes mesmo de terem se tornado carniça.

O sangue das tapuias mortas na colonização

A essência das negras arrastadas pelas senzalas

É, ó povo infame e cruento, vossa maldição! 
A cada companheira que cala e à tumba desce Morremos nós - ainda que vivas permaneçam Outras mil em fúria se levantarão! Vingaremos nossas irmãs ultrajadas As que na batalha em ardor foram forjadas Pois quem já morreu a Morte não pode matar. 